\title{
Biochemical characterization of Bacillus thuringiensis cytolytic $\delta$-endotoxins
}

\author{
Pandelakis A. Koni† and David J. Ellar \\ Author for correspondence: David J. Ellar. Tel: +44 223 333651. Fax: +44223333345. \\ e-mail: DJE1@MOLE.BIO.CAM.AC.UK
}

Department of Biochemistry, University of Cambridge, Cambridge CB2 1QW, UK.

\begin{abstract}
The entomocidal $\delta$-endotoxins CytA and CytB produced by Bacillus thuringiensis (Bt) subspecies israelensis and kyushuensis respectively showed a similar level of toxicity to mosquito larvae but were not toxic to the larvae of the lepidopteran Manduca sexta. CytA and CytB are also similar in sequence, predicted secondary structure and $\alpha$-helical content, the only obvious difference being a C-terminal fifteen residue 'tail' on CytB. Investigations of the function, if any, of the CytB C-terminal 'tail' showed that this $\delta$-endotoxin is highly expressed and forms inclusions in an acrystalliferous Bt mutant without the aid of the $20 \mathrm{kDa}$ 'helper' protein from Bt subspecies israelensis which is essential for CytA inclusion formation. After proteinase $K$ treatment, CytA and CytB were processed to virtually the same points in a sequence alignment and were equally haemolytic in vitro. However, the results suggested that unprocessed CytB differs from unprocessed CytA in that the former is not haemolytic.
\end{abstract}

Keywords: Bacillus thuringiensis, $\delta$-endotoxins, $\mathrm{Cyt} A, \mathrm{CytB}$

\section{INTRODUCTION}

Bacillus thuringiensis $(B t)$ is a Gram-positive bacterium which produces an insecticidal cytoplasmic protein inclusion during sporulation (Lüthy et al., 1982). Depending upon the subspecies, inclusions may be composed of one or more $\delta$-endotoxins which are variously toxic to the larvae of Lepidoptera, Diptera, Coleoptera or some combination thereof (Höfte \& Whiteley, 1989). The inclusions are ingested by susceptible larvae, solubilized by the high $\mathrm{pH}$ of the larval midgut (in the case of Lepidoptera and Diptera), and the protoxin is activated by proteases (Lüthy et al., 1982). The activated $\delta$-endotoxin then interacts with midgut epithelial cells via insectspecific receptors, creating membrane pores that cause cell swelling and lysis (Knowles \& Ellar, 1987).

Whilst most $\delta$-endotoxins are members of a family of sequence-related Cry $\delta$-endotoxins (Höfte \& Whiteley, 1989), at least three are not. These are two CytA $\delta$ endotoxins, from $B t$ subsp. israelensis (Ward \& Ellar, 1984; Waalwijk et al., 1985) and subsp. morrisoni PG14 (Earp \& Ellar, 1987), and CytB from subsp. kyushuensis

\footnotetext{
†Present address: MRC Neuroscience Group, Department of Neurobiology, Babraham Institute, Cambridge CB2 4AT, UK.

The EMBL accession number for the amino acid sequence reported in this paper is $\mathbf{Z 1 4 1 4 7}$
}

(Koni \& Ellar, 1993). Unlike Cry $\delta$-endotoxins, Cyt $\delta$ endotoxins display broad cytolytic activity in vitro (Thomas \& Ellar, 1983a; Chilcott \& Ellar, 1988; Knowles et al., 1992) as well as being specific to dipteran larvae in vivo (Armstrong et al., 1985; Knowles et al., 1990b). There is limited evidence that, besides being toxic to dipteran larvae, $\mathrm{CytB}$ causes feeding inhibition of the larvae of two lepidopteran species, Manduca sexta (Held et al., 1990) and Pieris brassicae (Knowles et al., 1992). This work was not conclusive however as these workers used either whole subsp. kyushuensis inclusions (Held et al., 1990), of which CytB comprises only about $30 \%$, or $\mathrm{CytB}$ partially purified from subsp. kyusbuensis inclusions (Knowles et al., 1992) of which CytB comprises only approximately $60 \%$.

The broad cytolytic activity of CytA in vitro has been attributed to its high hydrophobicity and its ability to bind to certain ubiquitous membrane lipids (Thomas \& Ellar, 1983b). Site-directed mutagenesis (Ward et al., 1988) suggested that although such receptor-independent membrane insertion can occur under certain conditions (Knowles et al., 1990a), an insect-specific receptor may be essential for toxicity in vivo. Support for the existence of a receptor comes from the demonstration of specific binding to mosquito midgut epithelial cell apical brush border membranes (Ravoahangimalala et al., 1993).

The $\mathrm{X}$-ray crystallographic structure of the CryIIIA $\delta$ endotoxin revealed that the sequence blocks conserved 
among Cry $\delta$-endotoxins are distributed between three distinct structural domains and suggested a functional role for each domain (Li et al., 1991). Although the X-ray crystallographic structure of a Cyt $\delta$-endotoxin has not yet been determined, the recent cloning and sequencing of a second Cyt $\delta$-endotoxin gene (Koni \& Ellar, 1993) enabled a predicted secondary structure model for Cyt $\delta$ endotoxins (Ward et al., 1988) to be further refined (Koni \& Ellar, 1993).

Further information on the structure of Cyt $\delta$-endotoxins has been obtained in this work by a combination of circular dichroism studies and comparison of proteolytic cleavage sites in $\mathrm{Cyt} A$ and $\mathrm{CytB}$. Expression of $c y t B$ ir. $B t$ has enabled a comprehensive comparison of the properties and toxicity of the products of both cloned $c y t B$ and cloned $\operatorname{cyt} A$ to be carried out. In vivo assays of $C_{y t} \delta$ endotoxins against dipteran and lepidopteran larvae were used to investigate the possibility that the broad in vitro cytolytic activity of these $\delta$-endotoxins was paralleled in vivo.

\section{METHODS}

Bacterial strains, plasmids, media and culture conditions. $B t$ strain IPS78/11 (Crickmore \& Ellar, 1992) was grown to iate exponential growth phase by overnight incubation in LuriaBertani (LB) broth or agar plates (Sambrook et al., 1989) at $30^{\circ} \mathrm{C}$. To obtain synchronous sporulation, IPS78/11 was grown in casein/casein/yeast extract (CCY) broth (Stewart et al., 1981) for $36-48 \mathrm{~h}$ using a $0 \cdot 1 \%$ inoculum of cell culture grown to exponential growth phase in LB broth using a heatshocked spore suspension (Ellar \& Posgate, 1974). Eschericibia coli TG2 (Sambrook et al., 1989) was grown on LB broth or agar plates (Sambrook et al., 1989) at $37^{\circ} \mathrm{C}$ overnight. For lai $Z \alpha$ promoter induction, $1 \mathrm{mM}$ IPTG was incorporated.

The Bt/E. coli shuttle vector used for subcloning was pSV2 (Crickmore \& Ellar, 1992). Other plasmids used were pCYTBXba1 and pCYTB (both containing the CytB protein gene; Koni \& Ellar, 1993) and cam2027 (possessing both cyt $A$ and the $20 \mathrm{kDa}$ 'helper' protein gene; Crickmore et al., 1990). Plasmids were selected for in cultures with either ampicillin $\left(100 \mu \mathrm{g} \mathrm{ml}^{-1}\right)$ or chloramphenicol $\left(5 \mu \mathrm{g} \mathrm{ml}^{-1}\right)$ as appropriate.

DNA manipulations. Plasmid DNA was obtained from cells by standard alkali lysis techniques (Sambrook et al., 1989), except that $B t$ cells were treated with lysozyme $\left(10 \mathrm{mg} \mathrm{ml}^{-1}\right)$ at $37^{\circ} \mathrm{C}$ for $30 \mathrm{~min}$ prior to alkali lysis. DNA modification and restriction enzymes were obtained from New England Biolabs and Gibco BRL. Restriction digests and DNA ligations were performed using Gibco BRL buffers. DNA was routinely electrophoresed on horizontal $0.5 \times$ TBE $[45 \mathrm{mM}$ Tris, $45 \mathrm{mM}$ boric acid, $1 \mathrm{mM}$ EDTA ( $\mathrm{pH} \mathrm{8.0)}$ ] agarose gels and visualized with ethidium bromide (Sambrook et al., 1989). If necessary, DNA fragments were purified from $1 \times$ TAE $[40 \mathrm{mM}$ Tris, $1 \cdot 14 \%(\mathrm{v} / \mathrm{v}$ ) glacial acetic acid, $1 \mathrm{mM}$ EDTA (pH 8.0)] agarose gels by the Geneclean II technique (BIO101) or by electroelution (Sambrook et al., 1989). E. coli TG2 was transformed by electroporation (Dower et al., 1988) as described previously (Koni \& Ellar, 1993). IPS78/11 was also transformed by electroporation (Bone \& Ellar, 1989) using settings of $1.8 \mathrm{kV}$, $600 \Omega, 25 \mu \mathrm{F}$ and a gap length of $0.4 \mathrm{~cm}$.

Expression plasmids for cytB in IPS78/11. pBTCYTB1 was made by ligating $c y t B$ on a $S a c I / S a l$ fragment from pCYTB (Koni \& Ellar, 1993) into the SstI and Sall sites of pSV2.
pBTCYTB2 was produced by blunt-end ligation of $c y t B$ into the $S m a I$ site of pSV2 on a Klenow end-filled DdeI fragment from pCYTBXbal (Koni \& Ellar, 1993). Both constructs were made by using $E$. coli TG2 as host and were then electroporated into IPS78/11. Prior to this, E. coli colonies transformed with pBTCY'TB2 were screened by restriction mapping to select clones which, like $\mathrm{pBTCYTB} 1$, had $c y t B$ in the same orientation as the vector chloramphenicol resistance gene.

Electron microscopy. Cell culture samples were fixed in $2 \%$ (v/v) glutaraldehyde/growth media mix (Agar Scientific) for $2 \mathrm{~h}$ before being washed three times for $5 \mathrm{~min}$ each in $50 \mathrm{mM}$ sodium cacodylate, $\mathrm{pH} 7 \cdot 3$ (Hopwood \& Milne, 1991). The sample was then fixed with $2 \%(\mathrm{w} / \mathrm{v}$ ) osmium tetroxide (Agar Scientific) for $1 \mathrm{~h}$ and washed as above. Fixed samples were then dehydrated, first with $50 \%(\mathrm{v} / \mathrm{v})$ ethanol and finally $100 \%$ ethanol, and embedded in Spurr's epoxy resin (Fisons Polaron). Thin sections were cut on a Sorvall Porter-Blum ultramicrotome MT-2 and dried down onto copper 200 square mesh support grids (Gilder Grids). Sections were stained for $30 \mathrm{~min}$ with $2 \%$ (w/v) uranyl acetate, for 2 min with Reynolds' lead citrate (Smith \& Croft, 1991) and then dried before viewing on a Philips EM300 transmission electron microscope at an accelerating voltage of $80 \mathrm{kV}$.

Isolation and manipulation of protein inclusions. $\mathrm{CytB}$ inclusions were released from $E$. coli cells by sonication. Inclusions were purified from lysed $B t$ and $E$. coli cell cultures by discontinuous sucrose density gradient centrifugation. To prevent aggregation of inclusions with spores prior to and during sucrose gradient centrifugation, inclusion/spore suspensions were not concentrated more than 100 -fold relative to the culture volume. Also, inclusion/spore suspensions and

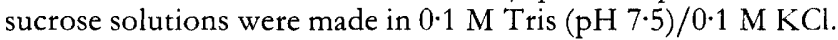
Inclusions were stored in water at $-20^{\circ} \mathrm{C}$ at concentrations of $1-10 \mathrm{mg} \mathrm{ml}^{-1}$ until required. Inclusions were solubilized at $37^{\circ} \mathrm{C}$ by incubation in either $50 \mathrm{mM} \mathrm{Na} \mathrm{CO}_{3}, \mathrm{pH} 10 \cdot 0$ or 10.5 , or in $50 \mathrm{mM} \mathrm{NH} \mathrm{NCO}_{3}, \mathrm{pH} 10.5$, with or without $10 \mathrm{mM}$ DTT. Unsolubilized material was removed by centrifugation at $12000 \mathrm{~g}$ in a microfuge for $15 \mathrm{~min}$. For proteolytic processing, solubilized material was treated with $0 \cdot 1-50 \%(\mathrm{w} / \mathrm{w})$ proteinase $\mathrm{K}$ at $37{ }^{\circ} \mathrm{C}$ for various times. For SDS-PAGE, soluble material was precipitated and the protease inactivated by adding 0.5 vols of $60 \%(\mathrm{v} / \mathrm{v})$ TCA and holding at $-20{ }^{\circ} \mathrm{C}$ for $2 \mathrm{~h}$. Precipitated material was prepared for subsequent gel electrophoresis by centrifugation at $12000 \mathrm{~g}$ in a microfuge for $30 \mathrm{~min}$ and washing once with acetone before vacuum desiccation. Citrate-precipitation of proteins prior to mosquito larvae (filter feeding) bioassays was carried out by a modification of the method of Chilcott \& Ellar (1988). Citric acid was added to lower the $\mathrm{pH}$ to approximately 4.5 and the sample then stored at $-20{ }^{\circ} \mathrm{C}$ for at least $2 \mathrm{~h}$ until required. Typically, $0 \cdot 1$ vols of $11 \%(\mathrm{w} / \mathrm{v})$ citric acid were added to $\delta$-endotoxin solubilized in $50 \mathrm{mM}$ $\mathrm{Na}_{2} \mathrm{CO}_{3}$, pH $10 \cdot 5$, with or without $10 \mathrm{mM}$ DTT. The material was then either used directly in mosquito larvae bioassays without further manipulation or repurified by centrifugation at $12000 \mathrm{~g}$ in a microfuge for $15 \mathrm{~min}$ and washed once with distilled water. The precipitate was then resuspended in distilled water and protein mass determined prior to use.

Protein mass determination. Inclusion/soluble protein mass refers to protein as estimated by the Lowry method using BSA fraction V (Sigma) as a standard. Where stated, inclusion protein mass was estimated by UV light absorbance at $280 \mathrm{~nm}$ by consideration of the number of moles of tyrosine and tryptophan per mole of protein and their extinction coefficients (Cantor \& Schimmel, 1980). To this end, protein inclusions were denatured using $8 \mathrm{M}$ urea $/ 6 \mathrm{M}$ guanidine. $\mathrm{HCl} / 50 \mathrm{mM}$ 


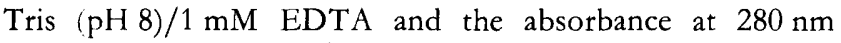
measured either immediately after the instantaneous solubilization of the inclusions, or after incubation at $37^{\circ} \mathrm{C}$ for $1 \mathrm{~h}$. An absorbance of 1.0 is equivalent to $48.8 \mu \mathrm{M}\left(1.3342 \mathrm{mg} \mathrm{m}^{-1}\right)$ Cyt $\mathrm{A}$ and $34.7 \mu \mathrm{M}\left(1.015 \mathrm{mg} \mathrm{ml}^{-1}\right) \mathrm{CytB}$.

Protein mass and composition were also determined by amino acid analysis of approximately $2 \mathrm{nmol}$ (about $50 \mu \mathrm{g}$ according to Lowry protein determination) of inclusions solubilized in $\mathrm{NH}_{4} \mathrm{HCO}_{3}(\mathrm{pH} \mathrm{10.5)/10} \mathrm{mM} \mathrm{DTT.} \mathrm{Protein} \mathrm{samples} \mathrm{were}$ lyophilized, hydrolysed in an argon atmosphere by the vapour from $6 \mathrm{M} \mathrm{HCl}$ containing $1 \%(\mathrm{v} / \mathrm{v}) 2$-mercapoacetic acid at $110^{\circ} \mathrm{C}$. for $24 \mathrm{~h}$, relyophilized and then analysed using a Pharmacia LKB Alpha Plus II sodium ion exchange system.

SDSPAGE \& immunoblot analysis. SDS-PAGE was carried out using the discontinuous buffer system (Laemmli \& Favre, 1973) as modified by Thomas \& Ellar (1983a). Before loading, an equal volume of loading buffer $[50 \mathrm{mM}$ Tris $(\mathrm{pH} 7.5) / 0.5 \mathrm{mM}$ EDTA $/ 0.5 \%$ SDS $/ 5 \%$ (v/v) glycerol/ $0.05 \%$ bromophenol blue $/ 25 \mathrm{mM}$ DTT] was added to each sample and then boiled for $5 \mathrm{~min}$. Protein size markers used were SDS-7 with added $\beta$-galactosidase (both from Sigma). Proteins were visualized by staining in $0.1 \%$ Coomassie blue $/ 10 \%(\mathrm{v} / \mathrm{v})$ methanol $/ 10 \%$ glacial acetic acid and then destaining in $10 \%$ methanol $10 \%$ acetic acid. Alternatively, proteins were transferred to nitrocellulose (Schleicher and Schuell) using an LKB Transblot semi-dry blotter, as described by the manufacturer. The success of the blotting was judged by staining the protein bands on the filter with $1 \%(\mathrm{w} / \mathrm{v})$ Ponceau $\mathrm{S} / 5 \%$ glacial acetic acid and then destaining with several washes of water. The membrane was then treated with $10 \mathrm{mM}$

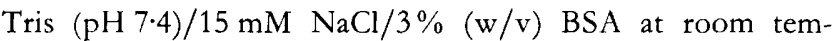
perature with gentle shaking for $1 \mathrm{~h}$ before anti-CytB antiserum (Koni \& Ellar, 1993) was added at a 1:2000 dilution and left for a further $2 \mathrm{~h}$. The membrane was then washed five times with

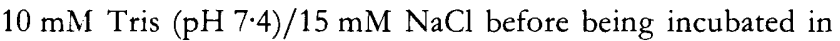
$10 \mathrm{mM}$ Tris ( $\mathrm{pH} 7 \cdot 4$ )/15 mM NaCl/3\% BSA and secondary antiserum (horseradish-peroxidase-conjugated anti-rabbit $\operatorname{IgG}$; Sigma) with gentle shaking for $1 \mathrm{~h}$. Secondary antiserum specifically bound to the filter was visualized by oxidation of 4-chloro-1-naphthol with hydrogen peroxide after washing as above.

$\mathrm{N}$-terminal protein sequencing. Proteins were subjected to SDS-PAGE in the presence of $2 \mathrm{mM}$ mercaptoacetic acid and then transferred onto Problot membrane (Applied Biosystems) using an LKB Transblot semi-dry blotter as described by the manufacturer. Proteins were visualized by Coomassie blue staining as described earlier and destaining with $50 \%$ methanol. After washing the membrane with water and then drying at room temperature, protein bands were excised and subjected to $\mathrm{N}$-terminal sequencing using an ABI 477A Applied Biosystems automated pulse-liquid sequencer.

Mass spectrometry. Electrospray mass spectrometry was performed using a BIO-Q quadrupole analyser (Loo et al., 1989) by VG Instruments connected to an Intel computer running on Lab-Base software. The mobile phase was pumped to the mass spectrometer using an Applied Biosystems 130A syringe pump, with a flow rate of $4 \mu \mathrm{min}^{-1}$ maintained while samples were analysed. Gramicidin-S was used as an internal standard at $2 \mathrm{mg} \mathrm{l}^{-1}$. The mass range scanned was calibrated using $20 \mu \mathrm{M}$ myoglobin (horse heart). After loading of the injection loop, samples were sprayed into the mass spectrometer source using a 34 gauge stainless steel capillary needle with a source temperature of $50{ }^{\circ} \mathrm{C}$. For positive ion analysis, the mobile phase and the myoglobin calibration solvent was $50 \%$ methanol $/ 1 \%$ acetic acid, the needle voltage was $4 \mathrm{kV}$ and samples were made to $50 \%$ methanol before analysis. For negative ion analysis, the mobile phase and the myoglobin calibration solvent was $50 \%$ acetonitrile, the needle voltage was $3 \mathrm{kV}$ and samples were made to $50 \%(\mathrm{v} / \mathrm{v})$ acetonitrile.

Circular dichroism spectroscopy. Circular dichroism was performed on a Jobin-Yvon CD 6 machine connected to an IBM PC Personal System/2, running CD6 and proteIn CONTIN-fit (Provencher \& Glockner, 1981; Provencher, 1982). Samples assayed were 1-2 $\mathrm{mg} \delta$-endotoxin $\mathrm{ml}^{-1}$ solubilized in $50 \mathrm{mM}$ $\mathrm{NH}_{4} \mathrm{CO}_{3}$ (pH 10.5) with or without $10 \mathrm{mM}$ DTT, from which an aliquot was set aside to accurately determine protein content by amino acid analysis. For processing of $\delta$-endotoxins, incubation was at $37^{\circ} \mathrm{C}$ for $16 \mathrm{~h}$ with $0 \cdot 1 \%$ proteinase $\mathrm{K}$. About $35 \mu \mathrm{l}$ of sample was loaded into a $0.1 \mathrm{~mm}$ gap cuvette and scanned seven times between $195 \mathrm{~nm}$ and $250 \mathrm{~nm}$ with an interval of $0.5 \mathrm{~nm}$ and $3 \mathrm{~s}$ for each reading. The average spectrum was then smoothed by averaging using a window of 5 points $(2.5 \mathrm{~nm})$. After subtraction of buffer/protease ellipticity, the $\delta$-endotoxin ellipticity was converted to molecular ellipticity for the purpose of CONTIN-fit $\alpha$-helical content determination by consideration of the molar concentration of the sample in terms of residues.

-SH group determination. - $\mathrm{SH}$ group content was determined by the method of Ellman (1959) after solubilizing $0.5-1.0 \mathrm{mg}$ of inclusions in $1 \mathrm{ml}$ of denaturant and determining the protein concentration by UV light absorbance.

Bioassays. Mosquito larvae bioassays were performed using 1-5-d-old Aedes aegypti larvae (reared from eggs supplied by Shell Research), Anopheles gambiae and Culex pipiens larvae (both obtained from the London School of Hygiene and Tropical Medicine as eggs). Both rearing and bioassays were performed at $30^{\circ} \mathrm{C}$ in a humidified incubator. Batches of $1000-4000$ larvae, depending upon the success rate of egg hatching, were reared in plastic containers $25 \times 25 \times 15 \mathrm{~cm}$ deep with about $5 \mathrm{l}$ of distilled water and Farley's Farex baby food as diet. Bioassays were performed in triplicate using 20 larvae in $1 \mathrm{~cm}$ diameter microtitre plate wells containing $0.9 \mathrm{ml}$ of the water in which the larvae were reared and $0.1 \mathrm{ml}$ of $\delta$-endotoxin. Negative controls contained only water. If, however, the $\delta$-endotoxin was citrate-precipitated and not repurified, negative controls contained a $90 \mu \mathrm{l}$ aliquot of $50 \mathrm{mM} \mathrm{Na} \mathrm{CO}_{3}(\mathrm{pH} \mathrm{10.5)}$ combined with a $10 \mu \mathrm{l}$ aliquot of $11 \%$ citric acid. Cyt $\mathrm{A}$ was used in parallel with $\mathrm{CytB}$ both as a positive control and also for comparison. Mortality was recorded after $24 \mathrm{~h}$.

$M$. sexta larvae bioassays were performed using 3-week-old larvae (first instar, $0.15-0.20 \mathrm{~g}$ in weight) reared on an artificial solid diet (J. Cayley, personal communication) from eggs supplied by Dr Stuart Reynolds (University of Bath). Both rearing and bioassays were performed at $25^{\circ} \mathrm{C}$ in a humidified incubator. Larvae were fed involuntarily with $2 \mu \mathrm{l}$ of $\delta$ endotoxin and then allowed to feed on unlimited solid diet for several days, during which body weight was monitored daily. Alternatively, larvae were allowed to feed voluntarily on a $3 \mathrm{~mm}$ high, $1 \mathrm{~cm}$ diameter disc of solid diet onto which $20 \mu \mathrm{l}$ of $\delta$ endotoxin had been adsorbed. This disc was consumed within $1-2 \mathrm{~d}$. The remains of this food were replaced with new, $\delta$ endotoxin-treated food each day and body weight monitored for several days. In all $M$. sexta bioassays, CryIA(c) and water were used as positive and negative controls, respectively.

Haemolysis assays were in microtitre plate wells at $25^{\circ} \mathrm{C}$ as described by Thomas \& Ellar (1983a) except that a $5 \%(\mathrm{v} / \mathrm{v})$ erythrocyte suspension was used. The erythrocytes used were prepared from New Zealand White rabbit blood, which was stored at $4{ }^{\circ} \mathrm{C}$ in Alsevers' solution $(0 \cdot 1 \mathrm{M}$ trisodium citrate $/ 40 \mathrm{mM}$ glucose) until use. $\delta$-Endotoxin was solubilized 


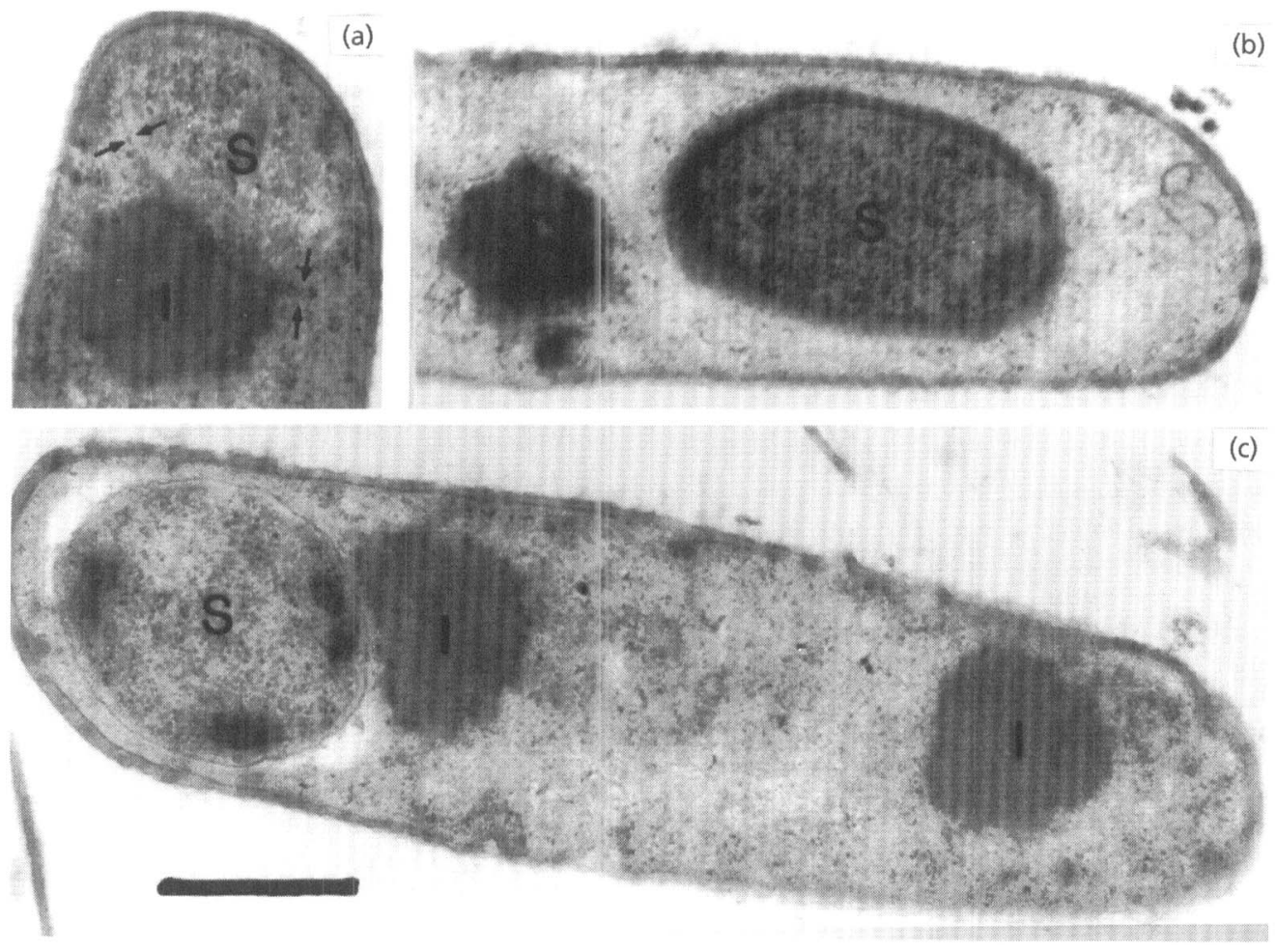

(b)

(c)

Fig. 1. Electron micrographs of CytB inclusions formed within IPS78/11 containing PBTCYTB1 during stages II (a), III (c) and IV (b) of sporulation (Bechtel \& Bulla, 1976). Spores and inclusions are marked by ' $S$ ' and ' $l$ ', respectively. The arrows shown on (a) delineate the forespore membrane. The size bar on (c) applies to all three micrographs and represents $0.5 \mu \mathrm{m}$.

and proteolytically processed with $10 \%$ proteinase $\mathrm{K}$ in $50 \mathrm{mM}$ $\mathrm{Na}_{2} \mathrm{CO}_{3}$, pH $10 \cdot 5$, with or without $10 \mathrm{mM}$ DTT as described earlier, and was then diluted 10 -fold in haemolysis buffer $[50 \%$ $(\mathrm{v} / \mathrm{v})$ phosphate-buffered saline $/ 2.25 \%(\mathrm{w} / \mathrm{v})$ glucose $/ 0.05 \%$ gelatin] prior to use. The end-point of haemolysis was judged after $3 \mathrm{~h}$ as the last dilution at which colouration of the liquid was still visible to the naked eye.

\section{RESULTS}

\section{Expression in Bt}

Cytoplasmic inclusions of Cyt $A$ are formed in the acrystalliferous $B t$ subsp. israelensis (Bti) strain IPS78/11 (Crickmore \& Ellar, 1992) when cyt $A$ is expressed together with the $B$ ti $20 \mathrm{kDa}$ 'helper' protein gene using the construct cam2027 (Crickmore et al., 1990). The latter has the 'helper' protein gene with its own promoter, mapped by Adams et al. (1989).

To express $c y t B$ in IPS78/11, two plasmids were constructed (see Methods) containing one or both of the putative promoter sequences identified previously (Koni \& Ellar, 1993) which are similar to sporulation-specific promoter sequences (Brown \& Whiteley, 1988; 1990). The first (pBTCYTB1) possessed only the middle-late sporulation-specific putative promoter upstream of the cyt $B$ coding sequence whereas the second (pBTCYTB2) contained both the early-middle and middle-late sporulation-specific putative promoters. Both constructs resulted in high $c y t B$ expression and inclusion formation during sporulation of IPS78/11. Fig. 1 shows that inclusions were seen as early as stage II of sporulation (Bechtel \& Bulla, 1976) even with pBTCYTB1. Immunoblot analysis of both vegetative cell cultures and the sedimentable fraction of lysed, sporulated cell cultures of IPS78/11 containing pBTCYTB1 and IPS78/11 containing pSV2 revealed that only sporulated cell cultures of IPS78/11 containing pBTCYTB1 produced sedimentable material of the size expected of $C y t B$ that cross-reacted with anti-CytB antiserum (Fig. 2, track 5). Both the purified E. coli and IPS78/11 inclusions (see next section) also showed a band approximately twice the size of $\mathrm{CytB}$ that cross-reacted with anti-CytB antiserum (Fig. 2, tracks 1 and 6), which is thought to be $\mathrm{CytB}$ dimer.

\section{Inclusion purification}

Both Cyt A and CytB inclusions from IPS78/11 and CytB inclusions from E. coli (Koni \& Ellar, 1993) were recovered at the interface between sucrose concentrations of $1.9 \mathrm{M}$ and $2.0 \mathrm{M}$. Small quantities of CytA and $\mathrm{CytB}$ inclusions from IPS78/11 were also present at the interface between sucrose concentrations of $2.0 \mathrm{M}$ and $2 \cdot 2 \mathrm{M}$ but were not harvested because of extensive contamination with spores. Recovery of both Cyt $A$ and CytB inclusions from IPS78/11 was $25-35 \mathrm{mg}^{2}$ protein $\mathrm{l}^{-1}$ whilst recovery of $\mathrm{CytB}$ inclusions from $E$. coli was 


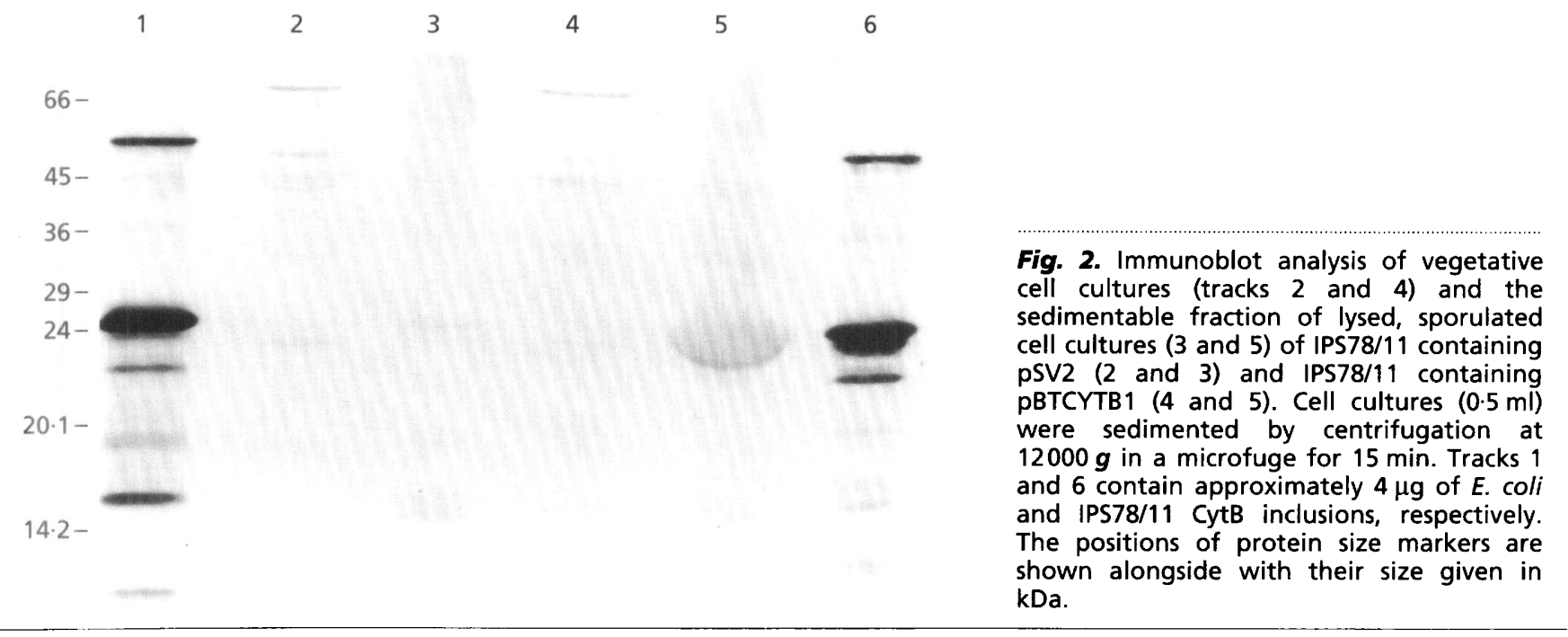

$150 \mathrm{mg}$ protein $\mathrm{I}^{-1}$, of which $\mathrm{CytB}$ accounted for about $40 \%$ (i.e. $60 \mathrm{mg}$ protein $\mathrm{l}^{-1}$ ).

\section{Inclusion solubilization}

$\mathrm{CytB}$ inclusions from $E$. coli were found to contain a significant amount of E. coli protein besides CytB (Fig. 3, track 2). However, $\mathrm{CytB}$ could be solubilized at concentrations as high as $5 \mathrm{mg}$ inclusions $\mathrm{ml}^{-1}$ with very little solubilization of the E. coli protein by incubation at $37^{\circ} \mathrm{C}$ for $1 \mathrm{~h}$ in either $50 \mathrm{mM} \mathrm{Na}_{2} \mathrm{CO}_{3}$, $\mathrm{pH} 10.0$ or 10.5 (Fig. 3, track 4), or in $50 \mathrm{mM} \mathrm{NH}_{4} \mathrm{HCO}_{3}$, pH 10.5. Proteolysis was not seen unless $10 \mathrm{mM}$ DTT was present (Fig. 3, track 6).

$\mathrm{Cyt} A$ and $\mathrm{Cyt} B$ inclusions from IPS78/11 were solubilized at concentrations as high as $2 \mathrm{mg} \mathrm{m}^{-1}$ by incubation at $37^{\circ} \mathrm{C}$ for $1 \mathrm{~h}$ in $50 \mathrm{mM} \mathrm{Na}{ }_{2} \mathrm{CO}_{3}, \mathrm{pH} 10 \cdot 0$ or $10 \cdot 5$, with $10 \mathrm{mM}$ DTT (Fig. 4) or in $50 \mathrm{mM} \quad \mathrm{NH}_{4} \mathrm{HCO}_{3}$ (pH 10.5)/10 mM DTT. Some proteolytic degradation of both $\mathrm{Cyt}_{\mathrm{A}} \mathrm{A}$ and $\mathrm{Cyt} \mathrm{B}$ was observed due to the presence of contaminating $B t$ proteases associated with the inclusions. However, this endogenous proteolysis was largely overcome by solubilizing the inclusions for $30 \mathrm{~min}$ on ice instead of at $37^{\circ} \mathrm{C}$ (Fig. 5).

$\mathrm{N}$-terminal sequencing established the $\mathrm{N}$-terminus of endogenously processed $\mathrm{Cyt} B$ to be residue 5 (see later, Fig. 7). There is a lysine residue at position 4 , suggesting the presence of a trypsin-like protease. Although the Cterminus was not established, it would appear from the size of endogenously processed $\mathrm{CytB}$ (Fig. 5, track 11) that some $\mathrm{C}$-terminal processing may also have occurred. Loss of the first four $\mathrm{N}$-terminal residues from unprocessed CytB should result in a reduction in size of only $542 \mathrm{Da}$ but endogenously processed $\mathrm{CytB}$ appears to be about $2 \mathrm{kDa}$ smaller than unprocessed $\mathrm{CytB}$ (Fig. 5).

Unlike the $C y t B$ inclusions from both $E$. coli and IPS78/11, CytA inclusions were almost insoluble at pH 10.0 in the absence of DTT and only about $20 \%$ soluble at $\mathrm{pH} 10.5$ without DTT after $1 \mathrm{~h}$ incubation at $37^{\circ} \mathrm{C}$ (Fig. 4). In vivo, inclusions may be solubilized by a combined effect of the alkaline gut $\mathrm{pH}$ and gut proteases. Therefore, Cyt A inclusions were incubated at $1 \mathrm{mg} \mathrm{ml}^{-1}$ in $50 \mathrm{mM} \mathrm{Na}_{2} \mathrm{CO}_{3}, \mathrm{pH} 10.5$, with $10 \%$ proteinase $\mathrm{K}$. No significant solubilization was seen after $5 \mathrm{~h}$ at $37^{\circ} \mathrm{C}$.

\section{Determination of molecular size from IPS78/11 inclusions}

Like native $\mathrm{Cyt} B$ from $B t$ subsp. kyushuensis inclusions (Earp et al., 1987), CytB from E. coli (Fig. 3) and IPS78/11 (Fig. 4b) appeared to be about $3 \mathrm{kDa}$ smaller than Cyt A by SDS-PAGE (Fig. 4a). This was despite the fact that the deduced coding sequence of $\mathrm{CytB}$ (Koni \& Ellar, 1993) revealed that $\mathrm{CytB}$ is actually $2 \mathrm{kDa}$ larger than $\mathrm{Cyt} A$ (Ward \& Ellar, 1984; Waalwijk et al., 1985). In order to determine whether or not the size of $\mathrm{Cyt} A$ and $\mathrm{Cyt} B$ in inclusions corresponded to a full length sequence, electrospray mass spectrometry was employed.

IPS78/11 CytB inclusions were solubilized at $1 \mathrm{mg} \mathrm{ml}^{-1}$ in $50 \%$ methanol $/ 10 \%$ acetic acid. Positive ion analysis revealed one major peak series whose molecular size was determined to be $58484 \pm 12 \mathrm{Da}$ (average from 16 peaks). This is precisely double the expected size of $\mathrm{Cyt} B$, suggesting that $\mathrm{CytB}$ was present in the inclusions as a dimer. In fact, a small amount of $\mathrm{CytB}$ dimer could be seen even by SDS-PAGE (Fig. 4b) and immunoblot analysis (Fig. 2, tracks 1 and 6). The mass spectrometry was repeated with inclusions solubilized on ice for $30 \mathrm{~min}$ with $50 \mathrm{mM} \mathrm{NH} \mathrm{HCO}_{3}$ (pH 10.5)/10 mM DTT instead of acetic acid. Again, $\mathrm{CytB}$ was found to be a dimer. However, negative ion mass spectrometry of $\mathrm{CytB}$ inclusions solubilized in $30 \%(\mathrm{v} / \mathrm{v}) \mathrm{NH}_{4} \mathrm{OH}$ revealed $\mathrm{CytB}$ to be in a monomeric form at $29293 \pm 16 \mathrm{Da}$ (average from 14 peaks). When further analysed, a minute quantity of material slightly smaller than full length $\mathrm{Cyt} B$ was revealed.

Positive ion mass spectrometry of CytA did not prove possible. Negative ion analysis was possible after solubilizing inclusions in $30 \% \mathrm{NH}_{4} \mathrm{OH} / 10 \mathrm{mM}$ DTT for $30 \mathrm{~min}$, revealing Cyt A to be mostly in a full length 


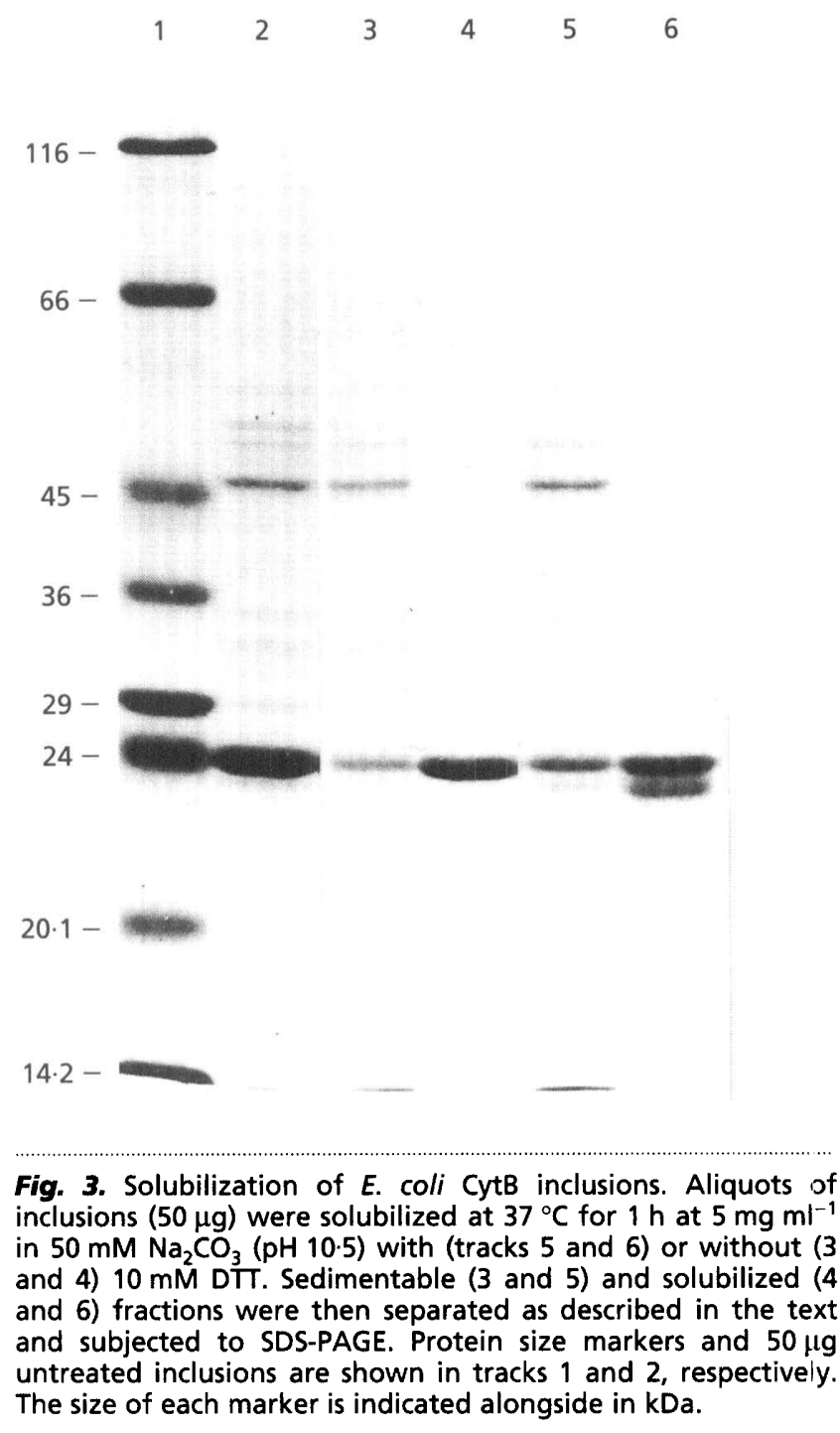

monomeric form of $27231 \pm 19 \mathrm{Da}$ (average from 1.2 peaks). As with $\mathrm{CytB}$, a small quantity of material that was not full length $C y t A$ was also present.

\section{-SH group content of IPS78/11 inclusions}

-SH group determination was carried out for both Cyt A and $C y t B$ inclusions from IPS78/11 on three separate occasions. Using protein mass as determined by UV absorbance for each individual assay, the $-\mathrm{SH}$ group content of $\mathrm{Cyt} A$ and $\mathrm{CytB}$ was found to be $36.7 \pm 2.3 \%$ and $21 \cdot 7 \pm 4 \cdot 3 \%$ of the theoretical maximum, respectively. Even if the determination of protein content was made by amino acid analysis as opposed to UV absorbance, the average - $\mathrm{SH}$ group content of CytA was still less than $47 \%$ whilst that of $\mathrm{CytB}$ was little changed. Control assays done with CryIIIA inclusions, which lack disulphide bonds (Carroll, 1990; MacIntosh et al., 1990), revealed at least $92 \%$ of $-\mathrm{SH}$ groups. These results suggested that both $\mathrm{Cyt} A$ and $\mathrm{Cyt} B$ exist in a largely disulphide-bonded state.

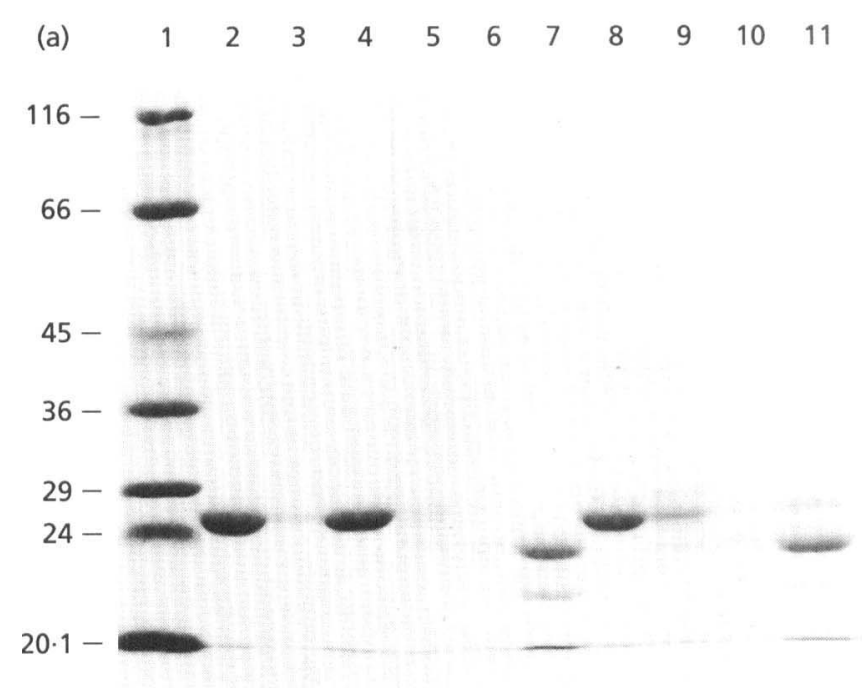

(b)

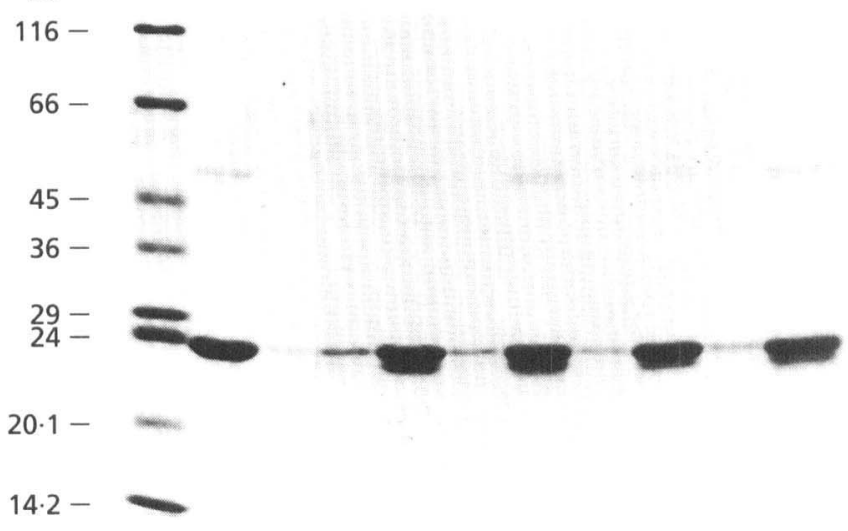

Fig. 4. Solubilization of CytA (a) and CytB (b) inclusions from IPS78/11. Aliquots of inclusions $(20 \mu \mathrm{g})$ were solubilized at $37^{\circ} \mathrm{C}$ for one $\mathrm{h}$ at $2 \mathrm{mg} \mathrm{ml}^{-1}$ in $50 \mathrm{mM} \mathrm{Na}_{2} \mathrm{CO}_{3}, \mathrm{pH} 10.0$ (tracks 4-7) or $\mathrm{pH} 10.5$ (8-11), with (6-7 and 10-11) or without (4-5 and 8-9) $10 \mathrm{mM}$ DTT. Alternatively, inclusions were suspended in deionised water alone ( 2 and 3 ). Sedimentable fractions (evennumbered tracks) and solubilized fractions (odd-numbered tracks) were then separated as described in the text and subjected to SDS-PAGE. Track 1 contains protein size markers, the sizes shown alongside in $\mathrm{kDa}$.

\section{Proteolytic processing}

Both Cyt A (Armstrong et al., 1985) and CytB (Knowles et al., 1992) are known to be protoxins. When solubilized at $1 \mathrm{mg} \mathrm{ml}^{-1}$ in $50 \mathrm{mM} \mathrm{Na}_{2} \mathrm{CO}_{3}(\mathrm{pH} 10 \cdot 5) / 10 \mathrm{mM} \mathrm{DTT}$ on ice and then incubated at $37^{\circ} \mathrm{C}$ in the presence of $0.1 \%$ proteinase $\mathrm{K}$, both $\mathrm{Cyt} \mathrm{A}$ and $\mathrm{Cyt} \mathrm{B}$ were completely processed to a single product in $1-3 \mathrm{~h}$. This processing was also achieved by incubation with $10 \%$ proteinase $\mathrm{K}$ for 5-10 min. However, upon prolonged ( $3 \mathrm{~h}$ ) incubation in $10 \%$ proteinase $\mathrm{K}$ the $\mathrm{CytB}$ product became unstable and was further processed to a second, smaller, stable product and eventually a third, even smaller product. Complete conversion to the smallest species was seen after 


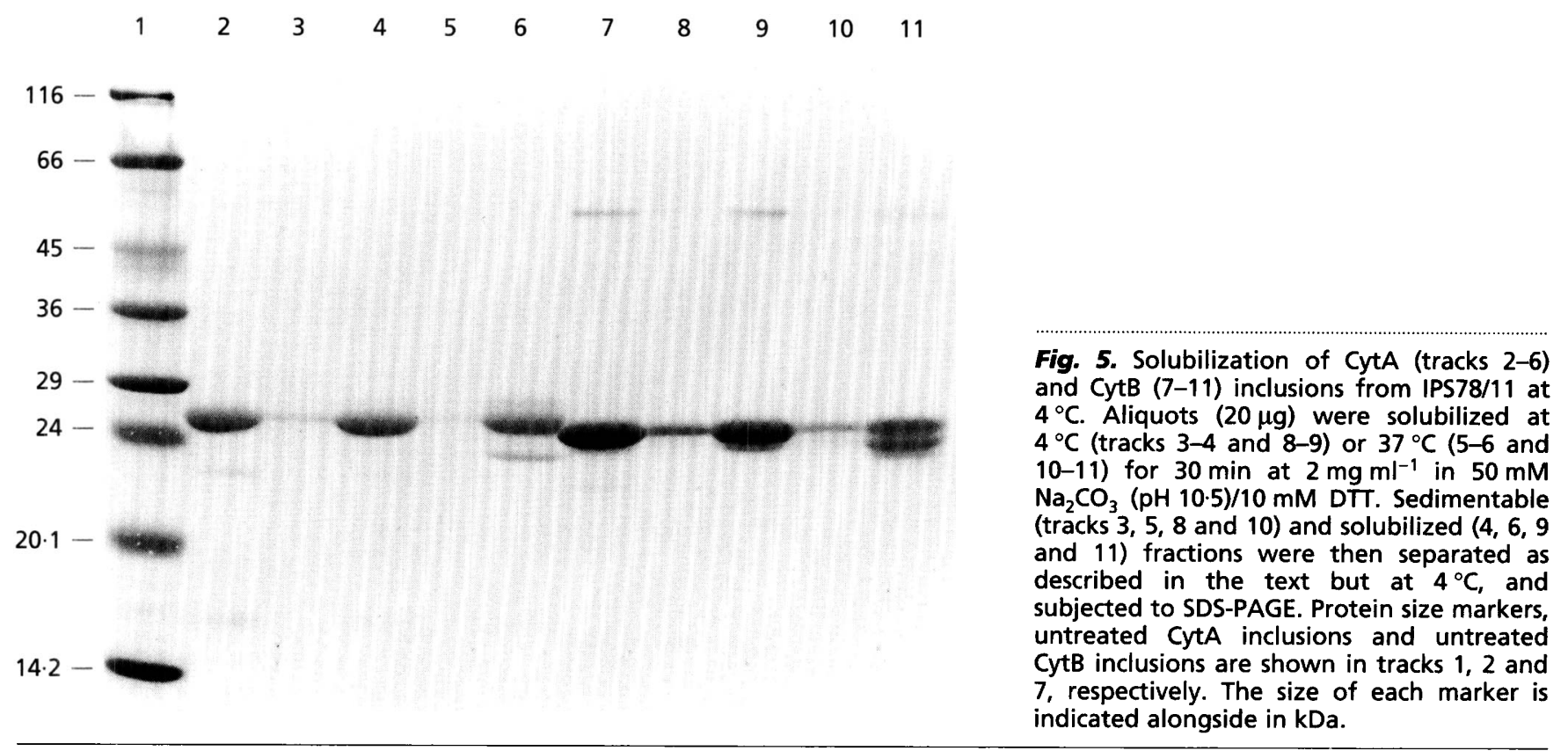

Table 1. Determination of Cyt $\delta$-endotoxin proteolytic processing sites

$\delta$-Endotoxin was used at a concentration of $1 \mathrm{mg} \mathrm{ml}^{-1}$. The three $\delta$-endotoxin sizes shown are the size estimated to the nearest $100 \mathrm{Da}$ by SDS-PAGE; the size determined by mass spectrometry to the nearest $\mathrm{Da}$; and the hypothetical size calculated using the Staden pip program (Staden, 1987) to the nearest $\mathrm{Da}$ based on the known N-terminus and the hypothetical C-terminus. The SD of the size as determined by mass spectrometry is of the order of that quoted in the text.

\begin{tabular}{|c|c|c|c|c|c|c|c|}
\hline \multirow[t]{2}{*}{ Toxin } & \multirow{2}{*}{$\begin{array}{c}\text { Protease } \\
\text { amount } \\
(\%, w / w)\end{array}$} & \multirow{2}{*}{$\begin{array}{l}\text { Proteolytic } \\
\text { processing } \\
\text { time } \\
\text { (h) }\end{array}$} & \multirow{2}{*}{$\begin{array}{c}\text { Known } \\
\text { N-terminal } \\
\text { residue }\end{array}$} & \multirow{2}{*}{$\begin{array}{l}\text { Hypothetical } \\
\text { C-terminal } \\
\text { residue }\end{array}$} & \multicolumn{3}{|c|}{ Size (Da) } \\
\hline & & & & & $\begin{array}{c}\text { Protein } \\
\text { gel }\end{array}$ & $\begin{array}{l}\text { Mass } \\
\text { spec. }\end{array}$ & $\begin{array}{c}\text { Hypothetical } \\
\text { C-terminal }\end{array}$ \\
\hline \multirow[t]{4}{*}{ CytA } & - & - & 1 & 249 & 27400 & 27321 & 27341 \\
\hline & 10 & $0 \cdot 2-0.5$ & 31 & 233 & 22500 & 22355 & 22365 \\
\hline & 10 & $0 \cdot 2-0 \cdot 5$ & 31 & 233 & 22500 & 22369 & 22365 \\
\hline & 50 & 16 & - & - & 22500 & - & - \\
\hline \multirow[t]{4}{*}{ CytB } & - & - & 1 & 259 & 24000 & $29242 *$ & 29236 \\
\hline & 10 & $0 \cdot 2-0.5$ & 34 & 238 & 21300 & 22865 & 22863 \\
\hline & 10 & $>16$ & - & - & 20400 & - & - \\
\hline & 50 & 16 & 38 & 230 & 20400 & 21520 & 21522 \\
\hline
\end{tabular}

* Size of unprocessed $\mathrm{Cyt} B$ when the size as determined by positive ion mass spectrometry is divided by two.

incubation in $50 \%$ proteinase $\mathrm{K}$ at $37^{\circ} \mathrm{C}$ for $16 \mathrm{~h}$ (Fig. 6 , track 6). Based on SDS-PAGE, the CytA product appeared unchanged even after treatment with $50 \%$ proteinase $\mathrm{K}$ for $16 \mathrm{~h}$.

A combination of $\mathrm{N}$-terminal sequencing and positive ion electrospray mass spectrometry was used to determine the $\mathrm{N}$ - and C-termini of the proteolytically-processed $\delta$ endotoxins. For mass spectrometry, IPS78/11 inclusions were solubilized at $1 \mathrm{mg} \mathrm{ml}^{-1}$ in $50 \mathrm{mM} \mathrm{NH} \mathrm{NHCO}_{3}$
(pH 10.5)/10 mM DTT on ice for $1 \mathrm{~h}$. Mass spectrometry of processed CytA proved to be very difficult but a single species was detected on two separate occasions, albeit at a relatively low signal intensity. The average molecular size observed by mass spectrometry was compared to the expected molecular size based on the determined $\mathrm{N}$ terminus and the hypothetical C-terminus (Table 1). Clearly, the expected and observed molecular sizes are very similar, and deviate by much less than the size of a single residue. 


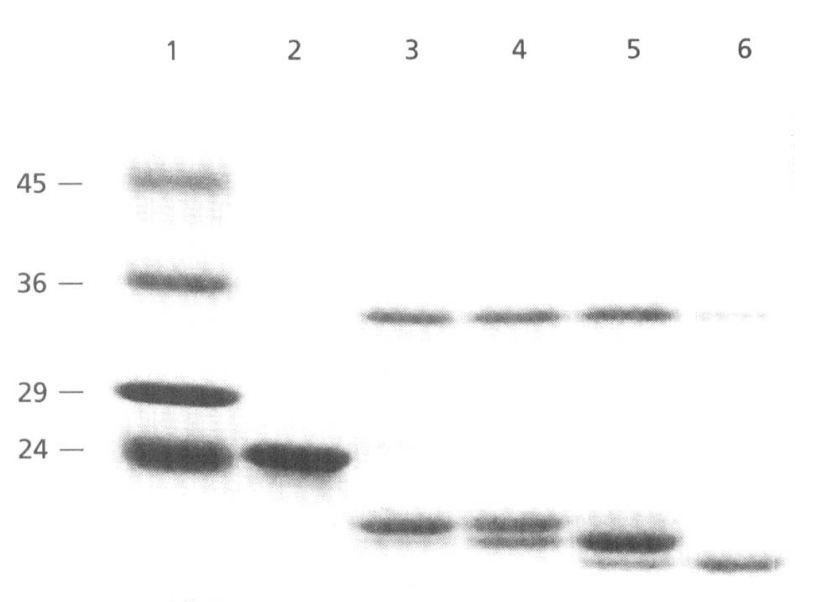

$20 \cdot 1-$ 20.98:

$14 \cdot 2$

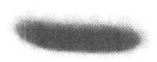

Fig. 6. Prolonged proteolytic processing of CytB inclusions from IPS78/11. Aliquots $(10 \mu \mathrm{g})$ were solubilized at $4{ }^{\circ} \mathrm{C}$ for $30 \mathrm{~min}$ at $1 \mathrm{mg} \mathrm{ml}^{-1}$ in $50 \mathrm{mM} \mathrm{Na}_{2} \mathrm{CO}_{3}$ pH 10.5, with $10 \mathrm{mM}$ DTT. Aliquots were then treated by addition of proteinase $\mathrm{K}$ to $50 \%$ (i.e. $0.5 \mathrm{mg} \mathrm{ml}^{-1}$ ). Incubation was at $37^{\circ} \mathrm{C}$ for $30 \mathrm{~min}$ (track 3), $60 \mathrm{~min}(4), 3 \mathrm{~h} \mathrm{(5)}$ and $16 \mathrm{~h}(6)$ before the reaction was stopped by TCA-precipitation. Samples were repurified as described in Methods and then subjected to SDS-PAGE. Tracks 1 and 2 contain protein size markers and untreated CytB, respectively. The size of each marker is shown alongside in $\mathrm{kDa}$. The intense band in tracks 3-6 of about $35 \mathrm{kDa}$ in size is proteinase $\mathrm{K}$.

In Fig. 7, the sites of proteolytic cleavage for Cyt $A$ and $\mathrm{Cyt} B$ are superimposed on the $\mathrm{Cyt} A / \mathrm{Cyt} B$ sequence alignment and consensus predicted secondary structure (Koni \& Ellar, 1993). This clearly reveals that CytA and $\mathrm{Cyt} B$ were processed to approximately the same points in the sequence alignment. Also, processing at the $\mathrm{N}$ terminal end occurred just as readily in $\mathrm{CytB}$ as in $\mathrm{Cyt} A$ (Table 1). The prolonged period of time required for full processing of $\mathrm{Cyt} B$ appeared to be due to resistance to proteolysis at the C-terminal end of the first stable processed product, at alignment position 247 (Fig. 7). Processing of the additional 15 residue C-terminal sequence itself appears to have occurred readily.

\section{Circular dichroism spectroscopy}

Amino acid analysis was performed in triplicate in order to establish an accurate protein concentration for samples which were to be used for circular dichroism, but at the same time revealed that the observed composition of Cyt $A$ and $C y t B$ was in close agreement to that expected (Waalwijk et al., 1985; Koni \& Ellar, 1993).

Circular dichroism in triplicate revealed processed Cyt A

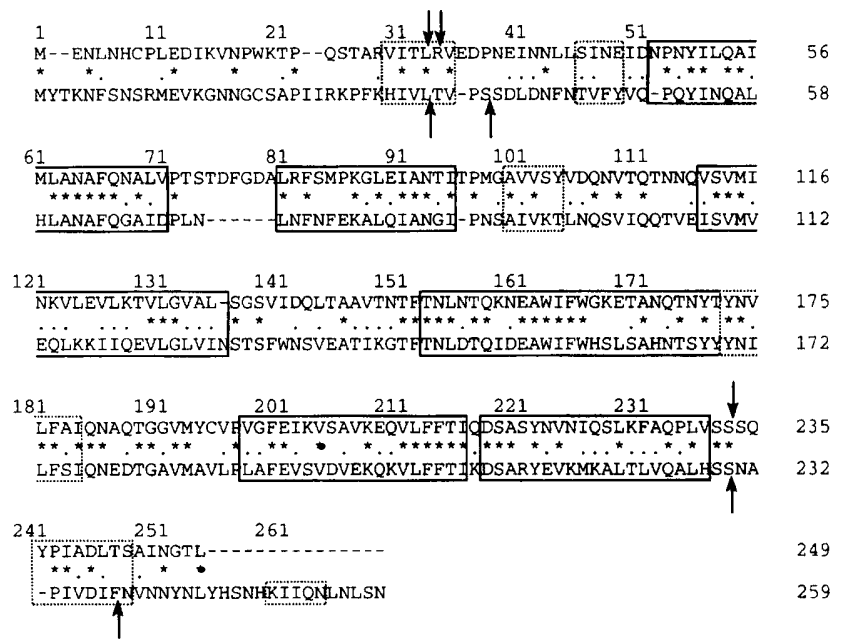

Fig. 7. Sequence alignment between CytA (upper sequence) and $C y t B$, with identical residue positions shown by asterisks and residues which are members of the same physicochemical group or which substitute well for each other (Bordo \& Argos, 1991) indicated by dots (Koni \& Ellar, 1993). Numbers above the alignment give an indication of the alignment position including the gaps, whereas those at the side are of the last residue on each line for the individual proteins. The regions in solid and dashed boxes are predicted to be conserved $\alpha$-helices and $\beta$-strands, respectively. The predicted secondary structure in the CytB additional C-terminal sequence is also shown. $\mathrm{N}$ - and C-terminal proteolytic processing sites are indicated by arrows. The outer $\mathrm{N}$-terminal arrow above the CytA sequence is that for a minor species (about $5 \%$ ) after processing for 30 min with $10 \%(w / w)$ proteinase $K$, whilst the inner arrow is that for the species referred to in Table 1 . The outer $\mathrm{N}$ - and C-terminal arrows below the CytB sequence are the cleavage sites after $30 \mathrm{~min}$ of $10 \%(\mathrm{w} / \mathrm{w})$ proteinase $\mathrm{K}$ treatment whereas the inner arrows mark the final product termini.

and processed $\mathrm{CytB}$ from IPS78/11 inclusions to be $57 \pm 1.8 \% \quad(115.7 \pm 3.7 \quad$ residues $)$ and $49 \pm 6.1 \%$ $(100 \pm 12.4$ residues) $\alpha$-helical. This compares to $45 \pm 2 \cdot 1 \%(91 \cdot 8 \pm 4 \cdot 3$ residues $)$ for processed $E$. coli $\mathrm{CytB}$ and $43 \pm 1.3 \%(111.4 \pm 3.4$ residues $)$ for unprocessed $\mathrm{CytB}$. These approximate to the expected value of 116 residues based on the consensus-predicted secondary structure model (Koni \& Ellar, 1993; Fig. 7).

\section{Toxicity to mosquito larvae}

Toxicity was tested against $2-5$-d-old $A$. aegypti and $C$. pipiens larvae and 4-5-d-old $A$. gambiae larvae. The data show that there is very little difference between $C y t A$ and CytB inclusions from IPS78/11 (Table 2), especially in view of the fact that $1 \mu \mathrm{g} C y+B$ is equivalent to only about $0.93 \mu \mathrm{g} \mathrm{Cyt} \mathrm{A} \mathrm{in} \mathrm{terms} \mathrm{of} \mathrm{moles} \mathrm{of} \delta$-endotoxin.

The efficiency of recovery of solubilized, unprocessed (i.e. solubilized at $4^{\circ} \mathrm{C}$ and not exposed to proteinase $\mathrm{K}$ ) Cyt A and $\mathrm{CytB}$ by citrate-precipitation was established to be virtually $100 \%$ and $75 \%$ respectively by protein mass determination after repurification. The lower recovery of $\mathrm{CytB}$ may not be too surprising in view of the fact that unprocessed $\mathrm{CytB}$ has a relatively high theoretical isoelectric point of about 7 (Koni \& Ellar, 1993). Com- 
Table 2. Mosquito larvae bioassays with IPS78/11 $\delta$-endotoxin inclusions

Figures represent the range of $\delta$-endotoxin concentrations for which approximately $50 \%$ mortality was seen, using a twofold serial dilution from $8 \mu \mathrm{g} \mathrm{ml} l^{-1}$. Probit analysis was not applied since the change in toxicity from one $\delta$-endotoxin dose to the next was often quite dramatic. At least five experiments were conducted for each $\delta$-endotoxin concentration, each experiment comprising assays in triplicate.

\begin{tabular}{|lcll|}
\hline Species & Age (d) & \multicolumn{2}{c|}{$\begin{array}{c}\text { Approx. } \mathbf{L C}_{50} \\
\left(\mu \mathbf{~ m i}^{-1}\right)\end{array}$} \\
\cline { 3 - 4 } & & CytA & CytB \\
\hline A. aegypti & 2 & $0 \cdot 5-1 \cdot 0$ & $1 \cdot 0$ \\
& 3 and 4 & $0 \cdot 5-1 \cdot 0$ & $1 \cdot 0-2 \cdot 0$ \\
& 5 & $1 \cdot 0$ & $2 \cdot 0-4 \cdot 0$ \\
A. gambiae & 4 & $1 \cdot 0$ & $1 \cdot 0$ \\
& 5 & $2 \cdot 0$ & $2 \cdot 0$ \\
C. pipiens & 2 & $0 \cdot 5-1 \cdot 0$ & $0 \cdot 5-1 \cdot 0$ \\
& 3 & $1 \cdot 0$ & $1 \cdot 0-2 \cdot 0$ \\
& 4 and 5 & $2 \cdot 0$ & $2 \cdot 0-4 \cdot 0$ \\
\hline
\end{tabular}

parison of the toxicity of citrate-precipitated unprocessed $\delta$-endotoxin compared to intact inclusions revealed the former to be as toxic as whole inclusions but no more so.

After precipitation with citric acid (Chilcott \& Ellar, 1988), processed CytA and all of the CytB proteolytic products seen were all equally as toxic to 2 -d-old $A$. aegypti larvae as unprocessed $\mathrm{Cyt} A$ and unprocessed $\mathrm{Cyt} B$.

\section{Toxicity to $M$. sexta larvae}

Involuntary feeding and inclusion-supplemented food assays were performed with $\mathrm{Cyt} A$ and $\mathrm{CytB}$ inclusions from IPS78/11. Inclusion-supplemented food assays were also performed with unprocessed $E$. coli $\mathrm{CytB}$ solubilized in $50 \mathrm{mM} \mathrm{Na}_{2} \mathrm{CO}_{3}(\mathrm{pH} \mathrm{10.5)}$ and with $\mathrm{Cyt} A$ and $\mathrm{CytB}$ solubilized in $50 \mathrm{mM} \mathrm{Na} \mathrm{CO}_{3}(\mathrm{pH} \mathrm{10.5)/10} \mathrm{mM} \mathrm{DTT}$ and processed with $10 \%$ proteinase $\mathrm{K}$ for $30 \mathrm{~min}$. Ten larvae were assayed at each $\delta$-endotoxin dose. As little as $5 \mathrm{ng}(0.038$ pmoles) of CryIA(c) caused complete feeding inhibition whereas none of the CytA nor CytB preparations caused any obvious feeding inhibition when $10 \mu \mathrm{g}$ (about 350 pmoles) was used. When inclusionsupplemented food assays were repeated using $100 \mu \mathrm{g}$ of $\delta$-endotoxin inclusions, again there was no obvious feeding inhibition.

\section{Haemolysis in vitro}

In order to study the in vitro cytolytic activity of Cyt $\delta$ endotoxins, microtitre plate haemolysis assays were employed. In experiments using essentially solubilized, unprocessed (i.e. solubilized at $4{ }^{\circ} \mathrm{C}$ and not exposed to proteinase $\mathrm{K}$ ) $\delta$-endotoxin from IPS78/11 inclusions, both Cyt A and CytB were found to be haemolytic (Table
Table 3. Haemolytic activity of unprocessed ('unknown') and processed ('endogenous' and 'full') Cyt $\delta$-endotoxins

Results were identical in three separate experiments. Alkali/protease negative controls were not haemolytic.

\begin{tabular}{|cccc|}
\hline Toxin & Source & Processing & $\begin{array}{c}\text { Haemolysis } \\
\text { end-point } \\
\left(\mu \mathrm{g} \mathrm{m}^{-1}\right)^{*}\end{array}$ \\
\hline CytA & IPS78/11 & Unknown & $0 \cdot 8$ \\
& & Endogenous & $0 \cdot 4$ \\
CytB & IPS78/11 & Full & $0 \cdot 2$ \\
& & Enknown & $3-6$ \\
& & Full & $0 \cdot 4$ \\
CytB & E. coli & Unknown & $>250$ \\
& & Full & $0 \cdot 2$ \\
\hline
\end{tabular}

* Amount of unprocessed toxin used to carry out the assay (rather than the mass of processed $\delta$-endotoxin after protease treatment).

3). 'Unprocessed' CytB from E. coli inclusions was not haemolytic until processed with proteinase $\mathrm{K}$, even when used at a concentration more than 40 -fold higher than that used for 'unprocessed' $\mathrm{Cyt} \mathrm{B}$ from IPS78/11 inclusions. This suggested that the problem of endogenous proteolysis of CytB from IPS78/11 inclusions seen after solubilization at $37^{\circ} \mathrm{C}$ had not been completely overcome by solubilization at $4{ }^{\circ} \mathrm{C}$. Thus, although others have demonstrated unprocessed CytA to be haemolytic (Chilcott \& Ellar, 1988), this cannot be confirmed with any certainty by the work here as 'unprocessed' CytA may also have been processed slightly by endogenous proteases.

Proteolytically processed CytA was only 4-fold more haemolytic than unprocessed CytA (Table 3). Processed CytB from both IPS78/11 and E. coli inclusions was at least 1200 times more haemolytic than unprocessed $\mathrm{Cyt} B$ from $E$. coli inclusions (Table 3 ). All of the proteinase Kgenerated products were equally haemolytic.

\section{DISCUSSION}

Both in the Bt strain IPS78/11 (this study) and E. coli (Koni \& Ellar, 1993), cytB was highly expressed and formed inclusions without the aid of the $B t i 20 \mathrm{kDa}$ 'helper' protein (Adams et al., 1989) or any other Bt subspecies kyushuensis gene. In contrast, $c y t A$ showed very low expression in both E. coli and IPS78/11 (a plasmidcured derivative of its native host) in the absence of the Bti $20 \mathrm{kDa}$ 'helper' protein (Adams et al., 1989; Crickmore et al., 1990). Even with the $20 \mathrm{kDa}$ 'helper' protein gene, cyt $A$ expression in E. coli was low (Adams et al., 1989; Visick \& Whiteley, 1991), whilst in $B t$ high expression and inclusion formation occurred (Crickmore et al., 1990; Chang et al., 1993; Wu \& Federici, 1993).

Cyt $\mathrm{A}$ is a mosquito-larvicidal $\delta$-endotoxin with a reported $50 \%$ lethal concentration of $0.1 \mu \mathrm{g} \mathrm{ml}^{-1}$ (Ward et al., 
1988) to greater than $1.0 \mu \mathrm{g} \mathrm{ml}^{-1}$ (Visser et al., 1986). This variation may have been partly due to the fact that toxicity varied with the age of the larvae (this work). In the present comparison between $\mathrm{Cyt} A$ and $\mathrm{Cyt} B$, there was very little difference between the two when in either their inclusion or citrate-precipitated forms. Since the data suggested that young larvae were more susceptible than older larvae, it may be that $A$. gambiae larvae less than $4 \mathrm{~d}$ old are also more sensitive. If this were true, $A$. gambiat would therefore be more susceptible than either $A$. aegypt $i$ or $C$. pipiens, the latter being least sensitive. A. gambiae larvae less than $4 \mathrm{~d}$ old were not employed because of the high mortality seen in negative controls with such young larvae.

Assays here with $M$. sexta larvae showed that as little as $5 \mathrm{ng}$ of CryIA(c) led to complete feeding inhibition. whereas 100000 times more $(100 \mu \mathrm{g})$ of Cyt $\mathrm{A}$ or $\mathrm{CytB}$ than CryIA(c) (in terms of moles) had no effect. Thus, the broad cytolytic activity of Cyt $\delta$-endotoxins in vitro is not paralleled in vivo. As mentioned in the Introduction, the growth inhibition of lepidopteran larvae observed by Held et al. (1990) and Knowles et al. (1992) may have been a result of the fact that these workers were using whole $B t$ subsp. kyushuensis inclusions in the former case and $\mathrm{CytB}$ partially purified from such inclusions in the latter case. Conceivably, the other proteins present in Bt subsp. kyushuensis inclusions (Earp et al., 1987) may prove to have lepidopteran toxicity.

The fact that $\mathrm{Cyt} A$ and $\mathrm{CytB}$ were proteolytically processed to the same site in the sequence alignment suggested that the two share the same general structure. However, it was noteworthy that the time required for processing to the same $\mathrm{C}$-terminal point was much longer for $\mathrm{CytB}$ than for $\mathrm{Cyt} A$. If the additional $\mathrm{C}$-terminal sequence in CytB (Koni \& Ellar, 1993) served to protect a $\mathrm{Cyt} B$ region against proteolysis, its absence in Cyt $\mathrm{A}$ could account for the different rates of proteolysis. This itself may partly explain why cyt $A$ was not highly expressed without the aid of the $B t i 20 \mathrm{kDa}$ 'helper' protein. Rapid proteolysis of CytA at the $\mathrm{C}$-terminal end may have prevented inclusion formation in the absence of the $B t i 20 \mathrm{kDa}$ 'helper' protein and therefore prolonged exposure to proteases, leading to complete degradation. However, it has been shown that the additional 15 residue $\mathrm{C}$-terminal sequence of $\mathrm{CytB}$ was not itself the most protease resistant element but that the high protease resistance lay in a region of the sequence alignment that Cyt $\mathrm{A}$ and $\mathrm{Cyt} \mathrm{B}$ apparently shared. Also, it has recently been shown that the additional 15 residue $\mathrm{C}$-terminal sequence can be removed from $\mathrm{CytB}$ at the genetic level and that this truncated $\mathrm{Cyt} B$ is still highly expressed in $E$. coli and is not haemolytic until proteolytically processed (P. A. Koni, M. Adams \& D. J. Ellar, unpublished). Nevertheless, it remains possible that $\mathrm{CytB}$ possesses a secondary structure in its C-terminal, proteolyticallyremoved region which is not in common with CytA and which is responsible for the observed proteolytic resistance.

Since $\mathrm{Cyt} B$ possesses only one cysteine residue (in the $\mathrm{N}$-terminal region that is removed by proteolytic pro- cessing), disulphide bonding would only result in the formation of dimers. CytA, on the other hand, possesses two cysteine residues (cysteine- 7 in the $\mathrm{N}$-terminal region that is removed by proteolytic processing, and cysteine190) and conceivably could form a large, insoluble network of molecules by intermolecular disulphide bonding. Thus it is interesting that $\mathrm{Cyt} A$ inclusions were not solubilized at $\mathrm{pH} 10.5$ or in $30 \% \mathrm{NH}_{4} \mathrm{OH}$ unless DTT was included, in $10 \%$ acetic acid or in $\mathrm{HCl}, \mathrm{pH} 1$ whereas $\mathrm{Cyt} \mathrm{B}$ inclusions from IPS78/11 were solubilized (data not shown). This behaviour reflects that of Cyt $A$ from native $B t i$ inclusions in that only about $40 \%$ of the Cyt A content of $B t i$ inclusions solubilized in $50 \mathrm{mM} \mathrm{Na}_{2} \mathrm{CO}_{3}, \mathrm{pH} 10.5$ (Thomas \& Ellar, 1983a). Furthermore, Bti inclusions contain disulphide bonds (Couche et al., 1987). Thus, the -SH content of both $\mathrm{Cyt} A$ and $\mathrm{CytB}$ inclusions from IPS78/11 were determined and found to be $36 \cdot 7 \pm 2.3 \%$ and $21 \cdot 7 \pm 4 \cdot 3 \%$, respectively.

If the insolubility of CytA inclusions were due to disulphide bonding, then both cysteine- 7 and cysteine- 190 would have to be involved. Certainly, surface exposure of cysteine-190 would be in agreement with work by Chow et al. (1989) who were able to modify proteolytically processed CytA with the cysteine modifier mercuryl chloride. Also, this region contains the epitope for a monoclonal antibody that inhibits toxin binding (Chow et al., 1989).

The significance, if any, of disulphide bonding in CytA toxicity is not known. When solubilized and then citrateprecipitated, CytA was as toxic as whole inclusions but no more so. Thus, it would appear that disulphide bonding is not an impediment to toxicity in vivo. It may be that disulphide bonds play a role in maintaining the inclusion state until ingestion by preventing solubilization under mild conditions, although there is no evidence to support this.

\section{ACKNOWLEDGEMENTS}

We would like to thank the Agricultural and Food Research Council for financial assistance; the Cambridge Centre for Molecular Recognition for help with protein sequencing, amino acid analysis, circular dichroism spectroscopy and electrospray mass spectrometry; Dr Neil Crickmore for providing pSV2 and cam2027; Mr Said Al-Yahyaee for determining the N-terminus of processed CytA; Mr Trevor Sawyer for hatching $M$. sexta eggs and providing CryIA(c); and Mr Dan Hill for assistance with electron microscopy.

\section{REFERENCES}

Adams, L. F., Visick, J. E. \& Whiteley, H. R. (1989). A 20-kilodalton protein is required for efficient production of the Bacillus thuringiensis subsp. israelensis 27-kilodalton crystal protein in Escherichia coli. J Bacteriol 171, 521-530.

Armstrong, J. L., Rohrmann, G. F. \& Beaudreau, G. S. (1985). Delta endotoxin of Bacillus thuringiensis subsp. israelensis. J Bacteriol 161 , 39-46.

Bechtel, D. B. \& Bulla, L. A. (1976). Electron microscopic study of sporulation and parasporal crystal formation in Bacillus thuringiensis. J Bacteriol 127, 1472-1481. 
Bone, E. J. \& Ellar, D. J. (1989). Transformation of Bacillus thuringiensis by electroporation. FEMS Microbiol Lett 58, 171-178.

Bordo, D. \& Argos, P. (1991). Suggestions for "safe" residue substitutions in site-directed mutagenesis. J Mol Biol 217, 721-729.

Brown, K. L. \& Whiteley, H. R. (1988). Isolation of a Bacillus thuringiensis RNA polymerase capable of transcribing crystal protein genes. Proc Natl Acad Sci US A 85, 4166-4170.

Brown, K. L. \& Whiteley, H. R. (1990). Isolation of the second Bacillus thuringiensis RNA polymerase that transcribes from a crystal protein gene promoter. J Bacteriol 172, 6682-6688.

Cantor, C. R. \& Schimmel, R. R. (1980). Biophysical Chemistry, part II, Techniques for the Study of Biological Structure and Function. San Francisco: W.H. Freeman \& Co.

Carroll, J. (1990). A study of the Bacillus thuringiensis insecticidal deltaendotoxins. $\mathrm{PhD}$ thesis, University of Cambridge.

Chang, C., Yu, Y.-M., Dai, S.-M., Law, S. K. \& Gill, S. S. (1993). High level $c r y I / D$ and $c y t A$ expression in Bacillus thuringiensis does not require the 20 -kilodalton protein, and the coexpressed gene products are synergistic in their toxicity to mosquitoes. Appl Environ Microbiol 59, 815-821.

Chilcott, C. N. \& Ellar, D. J. (1988). Comparative toxicity of Bacillus thuringiensis var. israelensis crystal proteins in vivo and in vitro. $J$ Gen Microbiol 134, 2551-2558.

Chow, E., Singh, G. J.P. \& Gill, S. S. (1989). Binding and aggregation of the 25-Kilodalton toxin of Bacillus thuringiensis subsp. israelensis to cell membranes and alteration by monoclonal antibodies and amino acid modifiers. Appl Environ Microbiol 55, 2779-2788

Couche, G. A., Pfannenstiel, M. A. \& Nickerson, K. W. (1987). Structural disulphide bonds in the Bacillus thuringiensis subsp. israelensis protein crystal. J Bacteriol 169, 3281-3288.

Crickmore, N. \& Ellar, D. J. (1992). Involvement of a possible chaperonin in the efficient expression of a cloned CryIIA $\delta$ endotoxin gene in Bacillus thuringiensis. Mol Microbiol 6, 1533-1537.

Crickmore, N., Bone, E. J. \& Ellar, D. J. (1990). Genetic manipulation of Bacillus thuringiensis: towards an improved pesticide. Aspects. Appl Biol 24, 17-24.

Dower, W. J., Miller, J. F. \& Ragsdale, C. W. (1988). High efficiency transformation of $E$. coli by high voltage electroporation. Nucleic Acids Res 16, 6127-6145.

Earp, D. J. \& Ellar, D. J. (1987). Bacillus thuringiensis var. morrisoni strain PG14: nucleotide sequence of a gene encoding a $27 \mathrm{kDa}$ crystal protein. Nucleic Acids Res 15, 3619.

Earp, D. J., Ward, E. S. \& Ellar, D. J. (1987). Investigation of possible homologies between crystal proteins of three mosquitocidal strains of Bacillus thuringiensis. FEMS Microbiol Lett 42, 195-199.

Ellar, D. J. \& Posgate, J. A. (1974). Characterisation of forespores isolated from Bacillus megaterium at different stages of development into mature spores. In Spore Research-1973, pp. 21-40. Edited by A. N. Barker, G. W. Gould \& J. Wolf. London: Academic Press. Ellman, G. L. (1959). Tissue sulfhydryl groups. Arch Biochem Biopbys 82, 70-77.

Held, G. A., Kawanishi, C. Y. \& Huang, Y.-S. (1990). Characterization of the parasporal inclusion of Bacillus thuringiensis subsp. kyushuensis. J Bacteriol 172, 481-483.

Höfte, H. \& Whiteley, H. R. (1989). Insecticidal crystal proteins of Bacillus thuringiensis. Microbiol Rev 53, 242-255.

Hopwood, D. \& Milne, G. (1991). Fixation. In Electron Microscopy in Biology: a Practical Approach, pp. 1-14. Edited by J. R. Harris. Oxford: IRL Oxford Press.
Knowles, B. H. \& Ellar, D. J. (1987). Colloid-osmotic lysis is a general feature of the mechanism of action of Bacillus thuringiensis $\delta$-endotoxins with different specificity. Biochim Biophys Acta 924, 509-518.

Knowles, B. H., Carroll, J. G., Horsnell, J. M. \& Ellar, D. J. (1990a). Interactions of a cytolytic toxin from Bacillus thuringiensis var. israelensis with liposomes and membranes. In Bacterial Protein Toxins, pp. 207-208. Edited by R. Rappuoli, J. E. Alouf, P. Falmagne, F. J. Fehrenbach, J. Freer, R. Gross, J. Jeljaszewicz, C. Montecucco, M. Tomasi, T. Wadstrom \& B. Witholt. Stuttgart: Gustav Fischer Verlag.

Knowles, B. H., Nicholls, C. N., Armstrong, G., Tester, M. \& Ellar, D. J. (1990b). Broad spectrum cytolytic toxins made by Bacillus thuringiensis. In Fifth International Colloquium on Invertebrate Patbology and Microbial Control: 1990, pp. 283-287. Adelaide, Australia: Society for Invertebrate Pathology.

Knowles, B. H., White, P. J., Nicholls, C. N. \& Ellar, D. J. (1992). A broad spectrum cytolytic toxin from Bacillus thuringiensis var. kyushuensis. Proc R Soc Lond Ser B Biol Sci 248, 1-7.

Koni, P. A. \& Ellar, D. J. (1993). Cloning and characterization of a novel Bacillus thuringiensis cytolytic delta-endotoxin. J Mol Biol 229, 319-327.

Laemmli, U. K. \& Favre, M. (1973). Maturation of the head of bacteriophage T4. I. DNA packaging events. $J$ Mol Biol 80, 575-599.

Li, J., Carroll, J. \& Ellar, D. J. (1991). Crystal structure of insecticidal $\delta$-endotoxin from Bacillus thuringiensis at $2.5 \AA$ resolution. Nature 353, 815-821.

Loo, J. A., Udseth, H. R. \& Smith, R. D. (1989). Peptide and protein analysis by electrospray ionization mass-spectrometry and capillary electrophoresis mass-spectrometry. Anal Biochem 179, 404-412.

Lüthy, P., Cordier, J.-L. \& Fischer, H.-M. (1982). Bacillus thuringiensis as a bacterial insecticide: basic considerations and applications. In Microbial \& Viral Pesticides, pp. 35-74. Edited by E. Kurstak. New York: Marcel Dekker.

Maclntosh, S. C., McPherson, S. L., Perlak, P. G., Marrone, P. G. \& Fuchs, R. L. (1990). Purification and characterization of Bacillus thuringiensis var. tenebrionis insecticidal proteins produced in E. coli. Biochem Biopbys Res Commun 170, 665-672.

Provencher, S. W. (1982). Contin - a general-purpose constrained regularization program for inverting noisy linear algebraic and integral-equations. Comput Phys Commun 27, 229-242.

Provencher, S. W. \& Glockner, J. (1981). Estimation of globular protein secondary structure from circular dichroism. Biochemistry 20, 33-37.

Ravoahangimalala, O., Charles, J.-F. \& Schoeller-Raccaud, J. (1993). Immunological localization of Bacillus thuringiensis serovar israelensis toxins in midgut cells of intoxicated Anopheles gambiae larvae (Diptera: Culicidae). Res Microbiol 144, 271-278.

Sambrook, J., Fritsch, E. F. \& Maniatis, T. (1989). Molecular Cloning: a Laboratory Manual, 2nd edn. Cold Spring Harbor, New York: Cold Spring Harbor Laboratory.

Smith, M. \& Croft, S. (1991). Embedding and thin section preparation. In Electron Microscopy in Biology: a Practical Approach, Pp. 17-37. Edited by J. R. Harris. Oxford: IRL Oxford Press.

Staden, R. (1987). Computer handling of DNA sequencing projects. In Nucleic Acids and Protein Sequence Analysis: a Practical Approach, pp. 173-218. Edited by M. J. Bishop \& C. J. Rawlings. Oxford: IRL Oxford Press.

Stewart, G. S. A. B., Johnstone, K., Hagelberg, E. \& Ellar, D. J. (1981). Commitment of bacterial spores to germinate. Biochem J 198, 101-106. 
Thomas, W. E. \& Ellar, D. J. (1983a). Bacillus thuringiensis var. israelensis crystal $\delta$-endotoxin: effects on insect and mammalian cells in vitro and in vivo. J Cell Sci 60, 181-197.

Thomas, W. E. \& Ellar, D. J. (1983b). Mechanism of action of Bacillus thuringiensis var. israelensis insecticidal $\delta$-endotoxin. FEBS Lett 154, 362-368.

Visick, J. E. \& Whiteley, H. R. (1991). Effect of a 20 -kilodaltor protein from Bacillus thuringiensis subsp. israelensis on production of the CytA protein by Eschericbia coli. J Bacteriol 173, 1748-1756.

Visser, B., Workum, M. V., Dullemans, A. \& Waalwijk, C. (1986). The mosquitocidal activity of Bacillus thuringiensis var. israelensis is associated with $\mathrm{M}_{\mathrm{r}} 230000$ and 130000 crystal proteins. FEMS Microbiol Lett 30, 211-214.

Waalwijk, C., Dullemans, A. M., van Workum, M. E. S. \& Visser, B. (1985). Molecular cloning and the nucleotide sequence of the
Mr 28000 crystal protein gene of Bacillus thuringiensis subsp. israelensis. Nucleic Acids Res 13, 8207-8217.

Ward, E. S. \& Ellar, D. J. (1984). Cloning and expression in Escherichia coli of the insecticidal $\delta$-endotoxin gene of Bacillus thuringiensis var. israelensis. FEBS Lett 175, 377-382.

Ward, E. S., Ellar, D. J. \& Chilcott, C. N. (1988). Single amino acid changes in the Bacillus thuringiensis var. israelensis $\delta$-endotoxin affect the toxicity and expression of the protein. J Mol Biol 202, 527-535.

Wu, D. \& Federici, B. A. (1993). A 20 -kilodalton protein preserves cell viability and promotes CytA crystal formation during sporulation in Bacillus thuringiensis. J Bacteriol 175, 5276-5280.

Received 8 September 1993; revised 26 January 1994; accepted 7 February 1994. 